\title{
Growing Soul Entrepreneurs Among Ahmad Technology And Business Institute Students Dahlan Jakarta Through Learning Method Student Centered Learning
}

\author{
Novfitri Landong Namora Sihombing \\ Ahmad Dahlan Institute of Technology and Business Jakarta \\ Correspondent: novfitri.lns@gmail.com
}

Submitted : June 20,2020 Revised : July 10,2020 Published : July 30, 2020

\begin{abstract}
Unemployment is one of the big problems commonly found in all countries in the world. Not only in developing countries, but also in developed countries. Specifically for Indonesia, the unemployment rate is still relatively high. The Central Statistics Agency (BPS) recorded the number of open unemployment in August 2019 of $5.28 \%$ or reaching 7.05 million people. The unemployment rate increased in number compared to August 2018 by 7 million people or decreased by a percentage of $5.34 \%$, The increase in TPAK gives an indication of the economic potential from the supply side of the increased workforce. Judging from the employment trends during August 2018-August 2019, this cannot be separated from the mindset of students in general. Students tend to want to become job seekers (job seekers) rather than job creators. Therefore, one of the efforts to reduce unemployment is by instilling and fostering an entrepreneurial spirit in students.Ahmad Dahlan Institute of Technology Jakarta as a technopreneur campus, specifically students have received entrepreneurship courses which include soft skills, leadership and entrepreneurship, in this case divided into 5 competency sections taught namely, character, communication and interpersonal, creativity and innovation, selling products and services, and business management. The five competencies are then organized into 14 meetings and entrepreneurial practices using the student centered learning method.
\end{abstract}

Keywords: Student Centered Learning, Entrepreneurship, Students, Entrepreneurial Soul

\section{INTRODUCTION}

Unemployment is one of the big problems commonly found in all countries in the world. Not only in developing countries, but also in developed countries. Specifically for Indonesia, the unemployment rate is still relatively high. The Central Statistics Agency (BPS) recorded the number of open unemployment in August 2019 of $5.28 \%$ or reaching 7.05 million people. The unemployment rate increased in number compared to August 2018 by 7 million people or decreased by a percentage of $5.34 \%$. Based on data from the Central Statistics Agency (BPS), The Open Unemployment Rate (TPT) has decreased from 2015 to 2019. In August 2019, the TPT fell to 5.28 percent compared to last year which was 5.34 percent. There are 5 unemployed out of 100 workforce in Indonesia. In line with the increase in the workforce, the Labor Force Participation Rate (TPAK) has also increased. August 2016 TPAK amounted to 67.49 percent, an increase of 0.23 percentage points compared to last year. The increase in TPAK gives an indication of the economic potential from the supply side of the increased workforce. Judging from the trends in employment during August 2018-August 2019, employment experienced an increase in percentage mainly in the Provision of Accommodation and Food and Beverage ( 0.50 percentage points), Manufacturing Industry (0.24 percentage points), and Trade (0.20 percent points). While employment fell, particularly in agriculture (1.46 percentage points), financial services $(0.06$ percentage points) and mining (0.04 percentage points). / employee / employee. There are 56.02 million people (44.28 percent) formal workers. Whereas there are 70.49 million people $(55.72$ percent) working in informal activities (including self-employed, trying to be assisted by temporary 
Growing Soul Entrepreneurs Among Ahmad Technology And Business Institute Students Dahlan Jakarta Through Learning Method Student Centered Learning

Sihombing

workers, casual workers, and unpaid workers) (55.72 percent). underemployed people (people who work less than 35 hours a week and are still looking for work or are still willing to accept work) and 28, 41 million part-time workers (people who work under normal working hours less than 35 hours a week but do not look for work or are not willing to accept other work). This can not be separated from the mindset of students in general. Students tend to want to become job seekers (job seekers) rather than job creators. Therefore, one of the efforts to reduce unemployment is by instilling and fostering an entrepreneurial spirit in students.

Entrepreneurship should begin with the formation of entrepreneurial characters, such as creativity, courage, confidence, the ability to negotiate, and the ability to speak. All of these characters can be applied in all courses. Giving entrepreneurship courses on campus is not enough, it cannot even foster student entrepreneurial spirit. To create an entrepreneurial spirit, entrepreneurship material provided by universities in general is good. However, the existing material is not accompanied by an appropriate learning process. The learning process still applies many one-way learning methods, which are centered on lecturers or instructors. So, it is not surprising that the dialogue that occurred was extremely minimal. Dare to speak and dialogue is one of the seeds of the entrepreneurial spiritAnother effective way to spawn an entrepreneurial spirit is to stimulate student creativity. The way to do this is by providing opportunities for students to do research and try to apply the theory learned in practice by motivating students, and is expected to be able to build an entrepreneurial spirit with creative ideas and innovations.

Ahmad Dahlan Institute of Technology Jakarta sAs a campus technopreneur, students specifically have received entrepreneurship courses that include soft skills, leadership and entrepreneurship, but this is still considered inadequate to foster entrepreneurial spirit, further additional programs are needed in entrepreneurship learning, the inclusion of entrepreneurship courses in the curriculum of each program Higher education studies certainly require a standardization of material and other supporting elements. Departing from this, there are several guidelines for universities in organizing entrepreneurship courses. in this case it is divided into 5 sections of competencies taught namely, character, communication and interpersonal, creativity and innovation, selling products and services, and business management. The five competencies are then arranged in 14 entrepreneurship meetings and practices, where the learning plan will be conducted for one semester for entrepreneurial competence. Based on the explanation above, we will explain things that can foster entrepreneurial spirit among students.

\section{METHOD}

Method of approach tostudent learning center. In applying the concept of Student-Centered Leaning, students are expected to be active and independent participants in their learning process, who are responsible and initiative to recognize their learning needs, find sources of information to be able to answer their needs, build and present their knowledge based on their needs and sources he found. Within certain limits, students can choose what they will learn

Student-centered learning (Student Centered Learning) has steps that require active participation from students, as follows (Afiatin, Tina, 2009):

a) Sharing information (Information Sharing) by brainstorming, cooperative, collaborative, group discussion (Gruop Discussion), panel discussion (symposium, and seminar);

b)Learning from experience (Experience Based) by means of simulation, role playing (Roleplay), games (Games), and group meetings;

c) Learning through problem solving (Problem Solving Based) by means of case studies, tutorials, workshops.

\section{RESULTS AND DISCUSSION}

If you look at the number of new entrepreneurial needs to position Indonesia as a developed country, at least it will take another 25 years to achieve it. These long time estimates 
Growing Soul Entrepreneurs Among Ahmad Technology And Business Institute Students Dahlan Jakarta Through Learning Method Student Centered Learning

Sihombing

require steps that need to be pursued immediately so that the number of new entrepreneurs can increase with a relatively short time of achievement. One step that can be done is to create new entrepreneurs who come from college graduates. The creation of college graduates who become entrepreneurs is not necessarily easy to implement. The only opportunity that is still very large is to work by starting an independent business. It's just rarely found someone who wants to start his life after graduating from college by starting a business. Such tendencies, resulting in high labor force residues in the form of educated unemployment. The number of tertiary education graduates is increasing every year. This condition is not proportional to the increased availability of job opportunities that will accommodate them. To grow and develop entrepreneurship among students can be implemented through the perturbation of Higher Education Curriculum. The curriculum is a set of plans and arrangements regarding the objectives, content, and learning materials as well as the methods used to guide the implementation of learning activities to achieve certain educational goals. To grow and develop entrepreneurship among students can be implemented through the perturbation of Higher Education Curriculum. The curriculum is a set of plans and arrangements regarding the objectives, content, and learning materials as well as the methods used to guide the implementation of learning activities to achieve certain educational goals. To grow and develop entrepreneurship among students can be implemented through the perturbation of Higher Education Curriculum. The curriculum is a set of plans and arrangements regarding the objectives, content, and learning materials as well as the methods used to guide the implementation of learning activities to achieve certain educational goals.

In the tertiary curriculum it is necessary to include several methods of learning in entrepreneurship courses in the study program. By being included in the curriculum in the study program, curricularly, students can learn about various theories and knowledge as well as entrepreneurial skills that can be used as provisions in pursuing and entering into the world of entrepreneurship both as students and especially after they finish their studies. The form of learning used is as follows:

\section{A. Student Learning Center Learning}

Student Centered Learningor SCL is a learning approach that is believed to be effective in improving the quality of learning of students. Of course, Student Centered Learning can be applied in lectures in tertiary institutions. Instead, students should be more actively involved in college activities compared to school children. However, it should be if students have high critical power. The best learning process is by involving students to actively understand the material. Meanwhile, lecturers play more of a role as facilitators. This can be described in Primada below:

\section{Figure 1. Learning Pyramid}

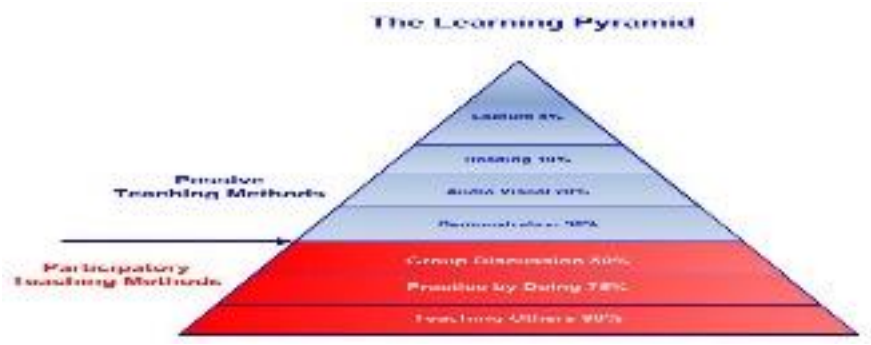

Based on the diagram above it can be seen that learning with a passive model through lectures, reading, audio visual, and demonstration is only able to produce a maximum achievement of $30 \%$. It is different if the learning process uses active learning methods through discussion, practice, and teaching others. The percentage of results that can be obtained can reach $50 \%, 75 \%$, and $90 \%$. Then it can be concluded that the active learning model is more trusted more effective for students. This Student Centered Learning method provides several benefits for students, including: 
Growing Soul Entrepreneurs Among Ahmad Technology And Business Institute Students Dahlan Jakarta Through Learning Method Student Centered Learning

Sihombing

\section{Students become the whole "civitas academica"}

Indeed in general, students are part of the civitas academica. But is it working properly? No, if students have not yet become an integral part of the academic community. In other words, students have not fully become academicians if their position is still the object of lecturer lectures. Moreover, if the assessment is determined only by how they can "repeat" the contents of the lecture on the worksheet during the exam.

\section{Increase learning motivation}

If students are aware of their role as civitas academica, they will be motivated to master the theory and continue to study. Not to mention if they are facilitated to participate in publishing scientific papers. In addition to conducting research, they can be motivated to write and publish the results of their research, both in the form of journals and books.

\section{More independent and responsible for learning}

By focusing on students, students are required to actively learn. They have to do research and then present it in college.

\section{Students can study more deeply}

Students have the opportunity to explore the field of science that is occupied independently, not bound by the material from the lecturer.

Not only students, lecturers also benefit from Student Centered Learning, namely L

\section{Your work as a lecturer is helped}

You don't have to prepare teaching materials or materials for every meeting. The preparation of teaching materials has been assigned to students. You only need to provide constructive evaluations or assessments related to material and conclusions from students.

\section{Integrate Tri Dharma of Higher Education}

With the SCL method, you invite students to actively conduct research and make it a learning material. That means you and your students "work together" in interpreting the Higher Education Tri Dharma in one performance or lecture.

\section{More professional}

If you are able to apply Student Centered Learning to students, it will be an additional skill for you. More importantly, you will also be helped to get inspiration and even a new source of study from the results of your students' research. This can continue, for example conducting research collaborations with related students. Of course, this will increase your professionalism as a lecturer.

From the explanation above, we need to believe that learning with the Student Centered Learning method is effective enough to improve the quality of student learning outcomes. Not only students, we as lecturers will also benefit. Therefore it is necessary to support student centered learning in the world of campus, the following is centered learning that can be done in the eyes of entrepreneurship courses:

TABLE 1. STUDENT CENTERED LEARNING LEARNING

\begin{tabular}{|c|c|c|}
\hline $\begin{array}{l}\text { Small Grovos } \\
\text { Diacuation }\end{array}$ & 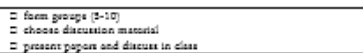 & 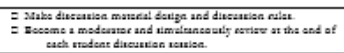 \\
\hline Sinvilasion & 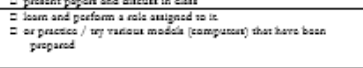 & 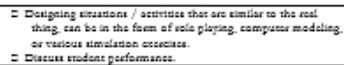 \\
\hline 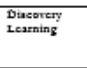 & 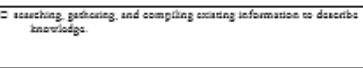 & 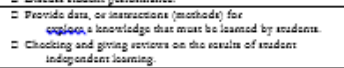 \\
\hline $\begin{array}{l}\text { Scil-Dintered } \\
\text { Learning }\end{array}$ & 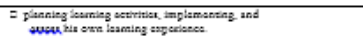 & 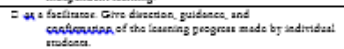 \\
\hline $\begin{array}{l}\text { Coaperativ } \\
\text { Lezrning }\end{array}$ & 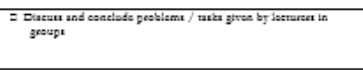 & 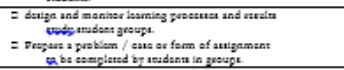 \\
\hline $\begin{array}{l}\text { Collaborative } \\
\text { Lesming }\end{array}$ & 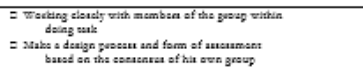 & 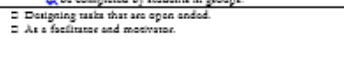 \\
\hline $\begin{array}{l}\text { Consexrual } \\
\text { Intrestion }\end{array}$ & 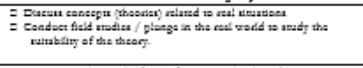 & 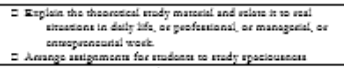 \\
\hline 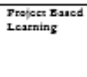 & 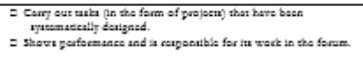 & 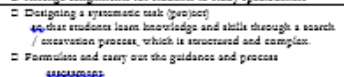 \\
\hline $\begin{array}{l}\text { Problem } \\
\text { Based on } \\
\text { Leaming }\end{array}$ & 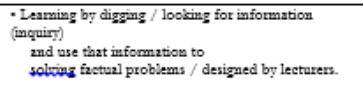 & $\begin{array}{l}\text { - Designing tziks to achiere competence } \\
\text { cortain } \\
\text { - Maks instruetious (methods) for students in finding } \\
\text { solutions to problems chosen by students } \\
\text { themselves or those specified }\end{array}$ \\
\hline
\end{tabular}


Growing Soul Entrepreneurs Among Ahmad Technology And Business Institute Students Dahlan Jakarta Through Learning Method Student Centered Learning

Sihombing

\section{B. Competency Based Learning Plan}

To strengthen the study of Study Centered Learning above it is necessary to make learning for entrepreneurial competencies as the table below:

TABLE 2. LEARNING PLAN FOR COMPETENCE: ENTREPRENEURSHIP

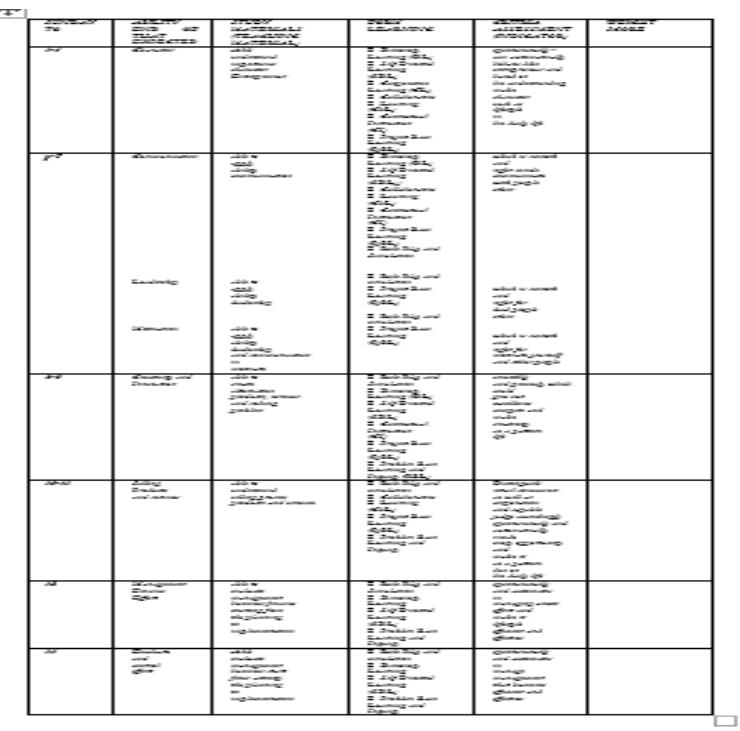

\section{PART 1: CHARACTER COMPETENCE}

In the first part of the entrepreneurship module is character competency. These character competencies are arranged using the competency formula approach as follows:Being able to understand the importance of entrepreneurial character and spontaneously-automatically

can behave like an entrepreneur and based on his understanding make the character as a pattern of life in his daily life

\section{PART 2: COMMUNICATION AND INTERPERSONAL COMPETENCE}

In the second part of the entrepreneurship module are communication and interpersonal competencies. These interpersonal and communication competencies are prepared using the competency formula approach as follows: able to apply leadership and communication skills that are smooth and precise to motivate themselves and others so that they can be a regular and neat person in building productive communication

\section{PART 3: CREATIFICATION AND INNOVATION COMPETENCY}

In the third part of the entrepreneurship module are creativity and innovation competencies. These creativity and innovation competencies are prepared using the competency formula approach as follows:able to create alternative products, services and problem solving smoothly and right that can provide competitive advantage and make creativity a pattern life

\section{PART 4: COMPETENCE OF SELLING PRODUCTS OR SERVICES}

In the fourth part of the entrepreneurship module is competency in selling products or services. Competence to sell this product or service is prepared using the competency formula approach as followsable to understand the process of selling products and services as a vein of business both to retail and corporate consumers and able to do it spontaneously and automatically in every opportunity and make it a pattern of daily life

\section{PART 5: BUSINESS MANAGEMENT COMPETENCY}

At the end of the entrepreneurship module is business management competence. This management competency is prepared using the competency formula approach as follows:able to evaluate business management from planning to implementation spontaneously and automatically managing family and business assets and making it an efficient and effective lifestyle 
Growing Soul Entrepreneurs Among Ahmad Technology And Business Institute Students Dahlan Jakarta Through Learning Method Student Centered Learning

Sihombing

\section{Entrepreneurial Practices}

After carrying out the learning and learning plan above then students are asked to apply all the lessons they have received by conducting entrepreneurial practices by following several bazaars under the guidance of entrepreneurial lecturers. Entrepreneurial practice is divided into several groups as the table below:

TABLE 3. DIVISION OF GROUPS

\begin{tabular}{|c|c|c|c|}
\hline GROUP 1 & GROUP 2 & GROUP & GROUP 4 \\
\hline Arew & Tepetale ro uke & Vepetable Foul & Cunm dips \\
\hline Wingho & Fudiug & Yellow the & Jably Crakas \\
\hline Finde: & Fried & & Frettr primaen olle \\
\hline
\end{tabular}

The first bazaar, Entrepreneurial practice was first started following the bazaar in commemoration of Teacher's Day, organizer of the bazaar from FKIP Open University. The bazaar was held on November 23, 2019 at the Open University Convention Center.

Figure 2. Bazaar at the Open University

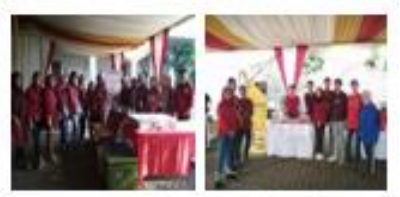

The second bazaar, The second time entrepreneurial practice, students took part in the Bazaar in commemoration of Violence Against Women on December 14-15, 2019 in front of the Ahmad Dahlan Institute of Technology Jakarta

Figure 3. Photo of Bazaar Activities in Front of Capable ITB Ahmad Dahlan Jakarta

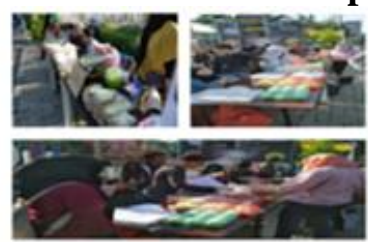

The last step After students practice entrepreneurship, students calculate sales revenue. In business, income is the amount of money received by the company from its activities, mostly from the sale of products and / or services to customers. For investors, income is less important than profits, which is the amount of money received after deducting expenses. The question that may often arise in the minds of novice entrepreneurs is how much profit my business has. After running a business with a variety of strategies needed, of course you have to know how much profit has been made, in order to be able to determine the next business decision. students simply make a report of sales results to find out the income obtained from the sale of their products,

\section{TABLE 4. SALES REVENUE}

\begin{tabular}{|l|l|l|}
\hline $\begin{array}{l}\text { Beginning balance } \\
\text { (IDR 100,000 X 9 People) }\end{array}$ & & Rp 900,000 \\
$\begin{array}{l}\text { Spending } \\
\text { Bottled Jelly Drink (100 bottles) }\end{array}$ & IDR 800,000 & IDR 800,000 \\
$\begin{array}{l}\text { Remainder } \\
\text { Sales }\end{array}$ & & \\
Jelly Drink (IDR 10,000 / bottle) & Rp 1,000,000 & \\
$\begin{array}{l}\text { Ending balance } \\
\text { The advantage }\end{array}$ & & IDR 1,100,000 \\
\hline
\end{tabular}

\section{CONCLUSION}

By running student center learning, it is hoped that entrepreneurial spirit can grow among students, this can be seen when students graduate from college. 
Growing Soul Entrepreneurs Among Ahmad Technology And Business Institute Students Dahlan Jakarta Through Learning Method Student Centered Learning

Sihombing

By implementing an entrepreneurial competency-based learning plan, we can measure student performance while participating in the entrepreneurship learning.

Students follow the practice of entrepreneurship. This is part of the practice of learning student centerd learning.

The sales income report is calculated and made as a material for further analysis to continue the business or not or change and rearrange new business proposals that have more economic value that can be beneficial for business people or students.

That not yet fully ITB Ahmad Dahlan Jakarta has and runs a centered learning program based on entrepreneurial competencies. This is due to the fact that lecturers or instructors do not understand or do not have student centered learning.

\section{REFERENCE}

Alesius Heri Pratono, SE, MDM, Economics of Small Business Behavior, Entrepreneurial Theory, Behavioral Concepts and Research Agenda, Graha Science, 978-602-262-782-8 (IESBN)

Djoko Sentoso, Director of the Directorate of Learning and Student Affairs of the Directorate General of Higher Education Ministry of Education and Culture, Entrepreneurship, Learning Module, 2013

Dr. Dearlina Sinag, SE, MM, Entrepreneur, Guidelines for Practitioners and Students, Ekulibria, 978-602-74984-1-9 (ISBN), 0, (EISBN)

https://www.bps.go.id/pressrelease/2019/11/05/1565/agustus-2019-- rate- unemploymentopen--tpt-- as big as 5-28-persen.html

https://www.duniadosen.com/student-centered-learning-b3/Beni Nurdiansyahon: November 08, 2016

https://republika.co.id/berita/noea62/grow-jiwa-kewirausaha-masiswa

SB Hari Lubis, " Entrepreneurship, Issue 1/3 SKS / "Module 1-9, ISBN 9789790116146, South Tangerang: Open University, 2014

Prof.Dr Rahmawati M.si Ak, Prof. Dr. Soenarto Msc, Arif Rahman Hakim SE, Sujadi Rahmat

Hidayat, Anastasia Riani Suprapti, Small Business Business Interprets Entrepreneurship Accounting and Marketing Management, Equalibria, 978-602-73096-7-8 (ISBN ), 0 (EISBN) 